${ }^{1}$ University of Ljubljana, Biotechnical Faculty, Department of Animal Science, Domžale, Slovenia

${ }^{2}$ University of Milan, Veterinary Faculty, Institute of Animal Nutrition, Milan, Italy

\title{
Functional analysis of the bovine beta- and kappa casein gene promoters using homologous mammary gland derived cell line
}

\author{
Dedicated to Prof. Dr. Dr. h.c. mult. Ernst Kalm on the occasion of his $65^{\text {th }}$ birthday
}

\begin{abstract}
Bovine casein gene cluster belongs to the best studied regions of the bovine genome. However, molecular basis of the regulation of casein gene expression is still of great interest for the advancement of milk production. Identification of crucial regulatory regions governing casein gene expression would provide valuable information for marker assisted selection in dairy cattle. In our study we performed comparative analysis of the bovine beta- and kappa casein gene promoter sequences with the regulatory sequences from some other species. In addition, we used homologous mammary gland derived cell culture and luciferase reporter gene system to confirm the functionality of the proximal beta and kappa casein promoters. The longer kappa casein promoter (2064 bp) showed the highest expression level, followed by the short kappa casein promoter (925 bp) and beta casein promoter (1692 bp). Here we demonstrate the suitability of the bovine mammary gland derived cell line BME UV1 for transient gene expression under transcriptional control of the bovine casein gene promoters and compare functionality of different fragments of bovine beta- and kappa casein gene promoters using homologous in vitro system.
\end{abstract}

Key Words: Bos taurus, bovine $\beta$ - and $\kappa-$ casein promoters, BME UV 1 cells, luciferase assay, STAT5

\section{Zusammenfassung}

Titel der Arbeit: Funktionsanalyse der Rinder $\beta$ - und $\kappa$-Kaseingenpromotoren mit Hilfe der homologen Euterzelllinie

Kasein Gen Cluster beim Rind gehören zu den am besten untersuchten Teilen des Rindergenoms. Trotzdem herrscht noch immer großes Interesse an detaillierten Studien über die molekulare Basis der Regulation der Kaseingen-Expression zur Steigerung der Milchproduktion. Die Entdeckung der Hauptregulationsmechanismen der Kaseingen-Expression wäre von großer Bedeutung für die markergestützte Selektion der Milchkühe. In unserer Studie haben wir die Promotorsequenzen der Rinder beta- und kappa- Kaseingene im Vergleich zu einigen anderen Säugetierarten untersucht. Die Rinder-Euterzellen BME UV1 und das Luziferase Reportergen System wurden für die Bestätigung der Funktionalität der Rinder $\beta$ - und $\kappa$-Kaseingenpromoters in vitro eingesetzt. Der längere $\kappa$-Kaseingen Promoter (2064 bp) hat die stärkste Expression gezeigt, gefolgt von dem kurzen $\kappa$-Kaseingen Promoter (925 bp) und dem $\beta$-Kaseingen Promoter (1692 bp). Hier können wir demonstrieren, dass die Rindereuterzelllinie BME UV1 für die vorübergehende Genexpression unter der Kontrolle der Rinderkaseingenpromotoren geeignet ist. Die Funktion von verschiedenen Teilen der Rinder $\beta$ und $\kappa$-Kaseingenpromotern wurde in einem homologen in vitro System verglichen.

Schlüsselwörter: Bos taurus, Rinder $\beta$ - und к- Kasein Promotoren, BME UV 1 Zellen, Luziferase assay, Stat5

\section{Introduction}

Caseins represent the most important protein fraction in bovine milk. Casein genes and regulation of their expression were, due to their economical importance, subject of 
extensive research in the past (GINGER and GRIGOR, 1999). Basic knowledge related to the biology of lactoprotein gene expression is therefore of crucial importance for the advancement of milk production. Identification of important regulatory elements and allele specific polymorphisms within the promoter regions of the bovine casein genes (JANN et al., 2002) would provide an interesting basis for the marker assisted selection in dairy cattle. Accumulation of genomic data during the last two decades enabled more focused research of molecular mechanisms governing casein synthesis in the mammary gland. Bovine casein genes are clustered on the chromosome 6 (BTA 6) within the region exceeding $200 \mathrm{~kb}$, of the casein locus cluster (RIJNKELS et al., 1997; FERRETTI et al., 1990), containing three paralogs encoding the calcium-sensitive $\alpha_{\mathrm{s} 1}-(\mathrm{CSN} 1 \mathrm{~S} 1), \alpha_{\mathrm{s} 2}-(\mathrm{CSN} 1 \mathrm{~S} 2)$ and $\beta-(\mathrm{CSN} 2)$ casein (BONSING and MACKINLAY, 1987), as well as an evolutionary unrelated $\kappa-(C S N 3)$ casein gene. The relative concentration of calcium sensitive caseins and $\kappa$-casein in the mammary gland is affected by casein genetic variants and has a significant impact on micelle size and technological properties of milk (LODES et al., 1996; GERNAND and HARTUNG, 1997; JUSZCZAK et al., 2001). In spite of the fact that casein composition varies considerably between species, $\kappa$-casein seems to be ubiquitous according to its biological role in micelle formation and stabilisation (MARTIN et al., 1993). Although all casein genes are co-ordinately expressed in a tissue- and stagespecific manner, there are considerable differences in the presence of conserved elements in the 5' flanking region of the $\kappa$-casein gene compared to the other three casein genes (GINGER and GRIGOR, 1999).

The most studies dealing with the regulation of bovine casein gene expression in the cell culture systems and transgenic animals were performed using $\beta$-casein promoter sequence (RIJNKELS et al., 1995; CERDAN et al., 1998). The DNA sequence analysis revealed several transcription factor (TF) binding sites in the proximal region of casein gene promoters. The majority of them play an important role in induction of transcription: STAT5, GR, NF1, C/EBP (ROSEN et al., 1999; HENNIGHAUSEN and ROBINSON, 1998; CHUGHTAI et al., 2002; WHEELER et al., 2001; YAMASHITA et al., 2001; WYSZOMIERSKI and ROSEN, 2001; ROBINSON et al., 1998; DOPPLER et al., 1995) while some of them also act as repressors: YY1, SOCS-1, SOCS-3, CIS3 (TOMIC et al., 1999; HELMAN et al., 1998). Their activation status in the mammary gland is mostly regulated by lactogenic hormones such as prolactin, hydrocortisone and insulin, and by growth factors as epidermal growth factor (EGF) and insulin like growth factor 1 (IGF-1) (ROSEN et al., 1999; HENNIGHAUSEN and ROBINSON, 1998). The most important transcription factor providing tissue specificity in milk protein gene expression is STAT5. It can be activated through the action of prolactin (PR) and growth hormone (GH) on JAK2/STAT signalling pathway or through the action of EGF on Src-kinase/STAT signalling pathway (GALLEGO et al., 2001). STAT5 activation is attained by phosphorylation and dimerisation, enabling translocation to the nucleus, binding of STAT5 dimers to DNA and contributing to the induction of transcription. Portions of $\beta$-casein gene promoter with significant effect on $\beta$-casein transcription rate, such as $\beta$-casein gene promoter enhancer element, named BCE1 have been identified and studied in vitro (SCHMIDHAUSER et al., 1992; MYERS et al., 1998).

In contrast to the $\beta$-casein gene, comprehensive studies of the $\kappa$-casein gene expression are scarce, in spite of its physiological and technological importance. The 
expression of the $\kappa$-casein gene has been studied in the lactating mammary gland of transgenic mice, but in contrast to a high expression levels of the closely linked $\alpha_{\mathrm{s} 1}$ and $\beta$-casein genes, the two more distal members of the cluster, $\alpha_{\mathrm{s} 2}$ and $\kappa$-casein genes, were not expressed at detectable levels (RIJNKELS et al., 1995). These findings were leading to an assumption, that there might be a cis-acting element present in the $\alpha_{\mathrm{s} 1} / \beta$ casein region, responsible for the expression of all four casein genes, so called "locus control region - LCR" (RIJNKELS et al., 1997). The quantitative analysis of allelic effects within the casein locus region revealed an evidence for epistatic effects (PIRCHNER and GRAML, 2003). However, functionality of a 570 bp fragment of the proximal $\kappa$-casein gene promoter has been confirmed in vitro in a heterologous cell system (ADACHI et al., 1996). In this experiment, the transfection of COS-7 cells resulted in no detectable CAT activity, whereas the mouse mammary epithelial cell line HC11 showed the measurable level of CAT expression under the transcriptional control of $570 \mathrm{bp}$ long $\kappa$-casein proximal promoter. The expression was comparable to the expression level under $\beta$-casein promoter (nt -930 to $n t+20$ ). In the region between nucleotides -439 and -125 of the $\kappa$-casein promoter, a functional regulatory element has been identified by deletion mutation analysis (ADACHI et al., 1996).

The majority of transfection experiments using bovine casein genes was performed using the mouse mammary gland derived cell lines (COMMA1D, HC11, C1D9), the cell lines, not specialised for expression of lactoprotein genes (CHO, COS-1 and COS7) or the bovine primary cell cultures (AHN et al., 1995). Bovine mammary gland derived cell lines were in the past mainly used in attempts to characterize the role of different growth factors/inhibitors during bovine mammary epithelial cell growth and for studying the interaction of pathogenic bacteria with bovine mammary epithelial cells (MATITASHVILI et al., 1997). Bovine mammary epithelial cell line BME-UV1 was established from the primary epithelial cells by stable transfection with a plasmid carrying a sequence of the SV40 thermolabile large T antigen (ZAVIZION et al., 1996) and used as a model system to examine mammary epithelial proliferation and differentiation as well as cell-to-cell communication (ZAVIZION et al., 1996; CHELI et al., 2003).

The purpose of our work was (i) to identify putative TF binding sites in the $\kappa$ - and $\beta$ casein gene promoter from different species by sequence analysis, (ii) to asses functionality of two potential STAT5 binding sites in the distal part of the $\kappa$-casein gene promoter and (iii) to establish the protocol for transient transfection of the BMEUV1 cell line in order to study the transcriptional activity of the bovine $\kappa$ - and $\beta$-casein gene promoters in a homologous in vitro system.

\section{Material and methods}

In silico identification of transcription factor binding sites

Putative TF binding sites in six $\kappa-\mathrm{CN}$ sequences and eight $\beta$-CN sequences of different species were determined using following consensus sequences: STAT5: TTCNNNGAA; YY1: CCATNT; GRE: NGTNCN; MAF: GPuPuGC/GAAG/T; NF1: TTGGC/ANNNNNT/GCCAA; (DOPPLER et al., 1995; KANAI et al., 1993; WATSON et al., 1991; WELTE et al., 1993). Casein promoter sequences were obtained from GenBank as follows: Bos taurus kappa-casein gene promoter (AF097400), Mus musculus kappa-casein gene, promoter region (AJ309571), 
Oryctolagus cuniculus kappa-casein gene, promoter region (AJ309572), Bubalus bubalis partial gene for kappa-casein, promoter region (AJ628346), Camelus dromedarius partial gene for kappa-casein, 5' flanking region (AJ409280), Ovis aries kappa-casein gene (L31372); Capra hircus beta-casein gene, promoter and exon 1 (AY311384); Rattus norvegicus beta-casein gene, promoter region (AY190602), Bubalus bubalis beta-casein gene, promoter region (AY352050), Camelus dromedarius partial gene for beta-casein, 5' flanking region(AJ409279), Homo sapiens beta-casein (CSN2) gene, complete cds (AF027807), Sus scrofa beta casein promoter region (E12614), Oryctolagus cuniculus DNA for 5'flanking region of beta-casein gene (X15735) and Bos taurus beta-casein promoter sequence (GenBank X14711). Searching for putative TF binding sites was performed by an in house TF binding site searching program.

Cloning of the 5' flanking sequence of the bovine $\kappa$ - and $\beta$-casein genes to pGL3 expression vector

For PCR amplification of the $\kappa$-casein gene promoter region, bovine BAC clone containing $\kappa$-casein gene was used (pBelo BAC11, bovine DNA, Laboratorie de Genetique Biochimique et Cytogenetique Jouy-en-Josas). Two promoter fragments of different size were amplified by PCR, both with 3' end corresponding to the transcriptional start site. Oligonucleotides used for the amplification contained an engineered restriction enzyme site. The shorter fragment JK12/13 was 925 bp long, and was amplified using JK12Xho.F (5'-ATTGCTCGAGTATTTTACTAAAATACC3'; XhoI site underlined) and JK13Hind.R (5'-TAAGAAGCTTACACCCAAGGTAAA TAAC-3'; HindIII site underlined) oligonucleotides. The longer, 2064 bp promoter fragment JK53/54, was amplified using oligonucleotides JK53mis.F (5'TAATGGGGTACCTTCAGGGTCAC-3'; KpnI site underlined) and JK54mis.R (5'CCACCTCGAGGAACACCCAAGGTAAA-3'; XhoI site underlined).

A 1692 bp long $\beta$-casein gene promoter fragment was PCR amplified using BBKpn.F (5'-ATCCGGTACCTCAAAATTGGTGAGAGACAG-3' with KpnI site underlined) and BBHind.R (AGTAAGCTTGGATAATGATCTGATTTTGTGGTTG; HindIII site underlined) oligonucleotides. The 3 ' end of the reverse oligonucleotide corresponds to the transcription start site. Bovine genomic DNA was used as a template.

All three promoter fragments were first subcloned in pGEM-TEasy plasmid. Plasmids containing promoter inserts were digested with HindIII and XhoI for the short $\kappa$ promoter fragment, KpnI and XhoI for the long $\kappa$-casein promoter fragment and KpnI and HindIII for the $\beta$-casein promoter fragment, purified by gel electrophoresis and subcloned into the pGL3-luciferase reporter vector (Fig. 1). The correct insertion of the promoter fragments 5' from the luciferase gene of pGL3 reporter vector was confirmed by sequencing using RV and GL primers (Promega). 


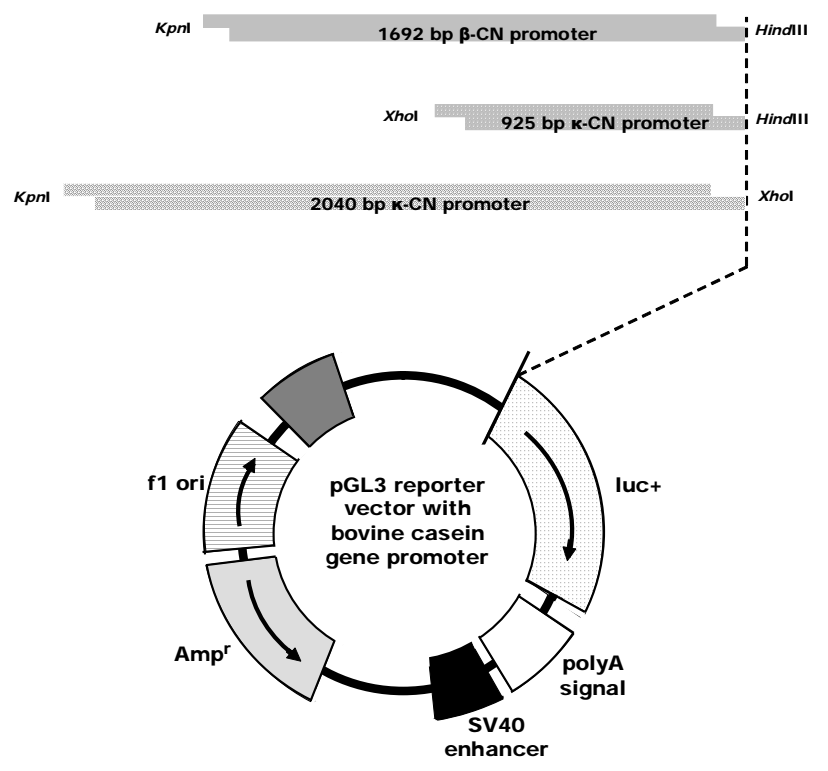

Fig. 1: Schematic representation of the bovine casein promoter-LUC constructs. Three different bovine casein promoter-LUC expression vectors BCN-LUC, sKCN-LUC and lKCN-LUC, harboring 1692 bp $\beta$-CN, 925 bp $\kappa-$ $\mathrm{CN}$ and 2064 bp $\kappa$-CN promoter fragments, respectively, were constructed by insertion of promoter sequences into pGL3-enhancer vector using appropriate restriction enzyme sites (Schematische Darstellung der Rinderkaseingenpromotor-LUC-Konstrukte. Drei unterschiedliche Rinderkaseingenpromotor-LUC-Expressionsvektoren, BCN-LUC, sKCN-LUC und lKCN-LUC, die 1692 bp des $\beta$-CN-, 925 bp des $\kappa-C N-$ beziehungsweise 2064 bp des $\kappa-\mathrm{CN}-$ Genpromotor beinhalten, wurden durch das Einsetzen der Promotorfragmente in den pGL3Enhancer Vektor mit Hilfe von geeigneten Restriktionsenzymen konstruiert)

Cell culture, transfection and expression assays

The novine mammary epithelial cell line BME-UV1was created at the University of Vermont (ZAVIZION et al., 1996). It originates from the primary mammary epithelial cells following microinjection with a plasmid carrying the sequence of the SV40 thermolabile large $\mathrm{T}$ antigen. Cells were cultivated on plastic, in growth medium containing 50\% DMEM, 30\% RPMI and 20\% NCTC-135. The medium was supplemented with FBS $50 \mathrm{ml} / \mathrm{l}$, penicillin $50 \mathrm{IU} / \mathrm{ml}$, streptomycin $50 \mathrm{IU} / \mathrm{ml}, 0.1 \%$ lactose, $0.1 \%$ lactalbumin hydrolysate, $1.2 \mathrm{mM}$ glutathione, $5 \mu \mathrm{g} / \mathrm{ml}$ transferrin and 10 $\mu \mathrm{g} / \mathrm{ml}$ L-ascorbic acid.

For transient transfections, BME-UV1 cells were seeded onto $60 \mathrm{~mm}$ plastic Petri dishes at cell density between $5 \times 10^{5}$ and $1 \times 10^{6}$ cells/ml. After $1-2$ days, cells were cotransfected with $10 \mu \mathrm{g}$ of promoter-pGL3 luciferase reporter vector and $6 \mu \mathrm{g}$ of $\beta$ galactosidase vector per well, using polybrene/DMSO assisted gene transfer method (AUBIN et al., 1994).

For determination of $\beta$-galactosidase ( $\beta$-gal) and luciferase activity, cells were lysed with $250 \mu \mathrm{l} 1 \mathrm{x}$ lysis buffer (Promega). Cell lysates were removed from the dishes with rubber policemen and transferred into $1.5 \mathrm{ml}$ centrifuge tubes, incubated under vigorous shaking for $10 \mathrm{~min}$ at $4^{\circ} \mathrm{C}$ and centrifuged at $20000 \mathrm{~g}$ for $30 \mathrm{~s}$. Aliquots of the supernatant were taken for determining either $\beta$-gal or luciferase activity.

$\beta$-gal activity was determined by adding $40 \mu \mathrm{l}$ of cell-lysate to the reaction mixture, containing ONPG (o-nitrophenil- $\beta$-D-galactopiranoside; Sigma) and measuring $\mathrm{A}_{420}$. $\beta$-gal activity was used for normalization of the luciferase assay.

The luciferase assay was performed by mixing $50 \mu \mathrm{l}$ of LAR (luciferase assay reagent, Promega) and $10 \mu \mathrm{l}$ of cell-lysate. Luminescence was measured on a Turner type 
luminometer. Measurements were corrected for unspecific luminescence by employing extracts from non-transfected cells.

\section{Results}

Putative transcription factors binding sites in the bovine $\kappa$ - and $\beta$-casein gene promoter Bovine $\kappa$-casein promoter (2140 bp) was sequenced previously (DEBELJAK et al., 2000, GenBank AF097400) and used together with five $\kappa$-casein promoter sequences and eight $\beta$-casein promoter sequences for identification of putative TF binding sites. TF binding sites were determined based on the perfect sequence match with the consensus binding site sequences reported in the literature. Comparing the organisation of the bovine $\kappa$-casein gene promoter with $\kappa$-casein promoters of other species (Fig. 2A), a very similar organisation of putative TF binding sites, especially in ruminant species was observed. The density of TF binding sites in the proximal 750 bps of the promoter in all species is relatively low with only a few potential GRE-1/2 sites, whereas the frequency of $\mathrm{TF}$ binding sites was higher between nucleotide positions -750 and -1300 . In this region, two potential STAT5 binding sites were found in all species, but in ruminant species (cattle and buffalo, the promoter sequence from the sheep, available in the GenBank was not long enough to cover this region entirely) in this region three evenly spaced STAT5 binding sites were found.

In the buffalo an extra distal STAT5 site was found in the region around -1900 and in the dromedar in the region between nucleotides -750 and -1300 four STAT5 binding sites were identified. The majority of promoters harbour three to four GRE-1/2 and one or two potential YY1 repressor binding sites in this region. Bovine promoter also contains potential MAF binding site, placed around nt -1600. Organisation of the rabbit and murine $\kappa$-casein promoters differs from that observed in ruminants. They have only two potential STAT5 binding sites within the first 2000 nucleotides and in the murine promoter potential YY1 binding sites are lacking entirely. In addition, one to two C/EBP and one to five AP-1 binding sites were found in the $\kappa$-casein promoters from different species. In the mouse and sheep promoter also OCT-1 binding site was present (data not shown in Fig. 2A).

In the case of $\beta$-casein promoters (Fig 2B), larger differences were observed between ruminants and non-ruminants. The organisation of potential TF binding sites in the bovine $\beta$-casein promoter is most similar to that of the goat and does not differ largely from the organisation of TF binding sites in $\beta$-casein promoters of other ruminants. Potential enhancer regions in these species seem to be placed between -750 and -1000 and between -1500 and -2050 (beta casein enhancer, BCE-1 element). The similar organisation of TF binding sites was observed in the pig $\beta$-casein promoter, while the organisation of TF binding sites in the $\beta$-casein promoters of other non-ruminant species differs considerably.

Comparing $\kappa$ - and $\beta$-casein promoters, it could be shown that they contain the same TF- binding sites, but they are organized in a different way. For the $\kappa$ casein gene promoters was typical clustering of STAT5 binding sites in the region between nucleotides -750 and -1300 , whereas the distribution of TF binding sites in the $\beta$ casein promoters is more disperse. 


\section{Kappa casein}

Oryctolagus cuniculus

Mus musculus

Camelus dromedarius

Ovis aries

Bubalus bubalis

Bos taurus

\section{Beta casein}

Homo sapiens

oryctolagus cuniculus

Sus scrofa

Rattus norvegicus

Caprahircus

Camelus dromedarius

Bubalus bubalis

Bos taurus
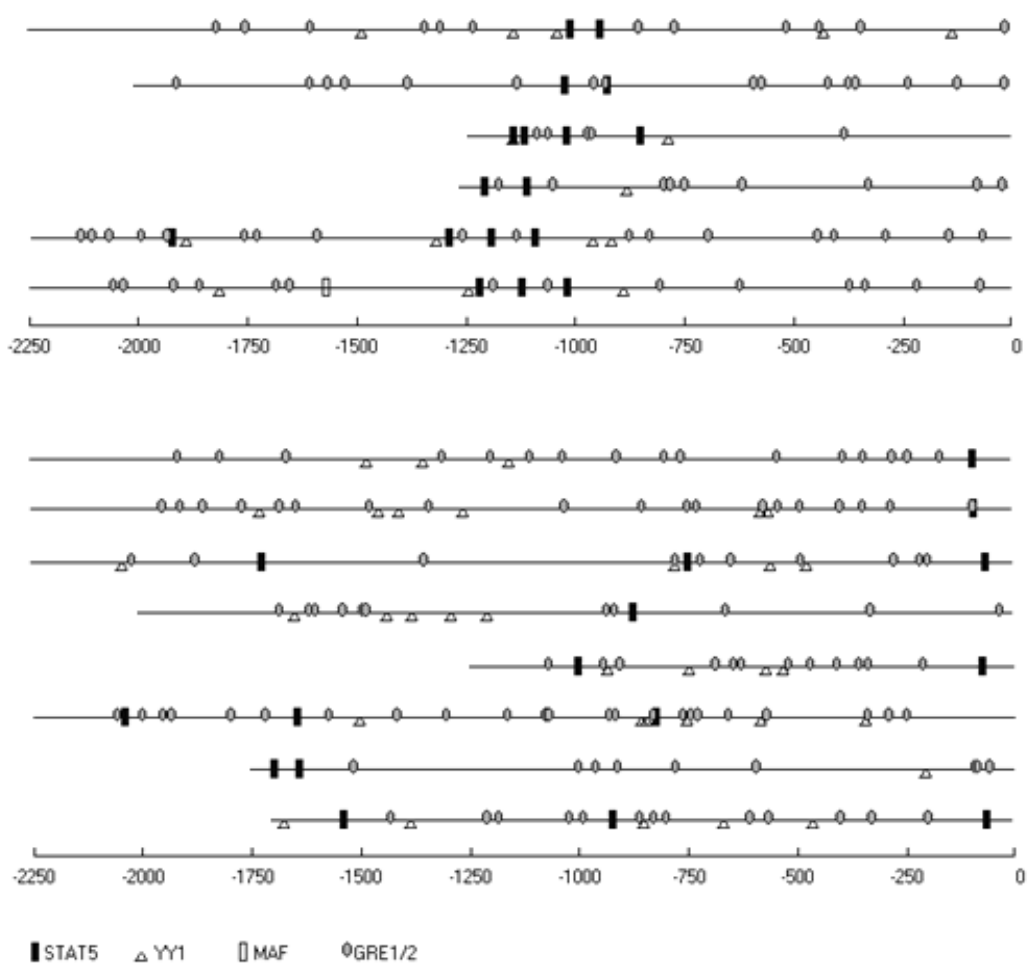

Fig. 2: Diagrammatic representation of putative transcription factor binding sites in six $\kappa$-casein promoter sequences and eight $\beta$-casein promoter sequences of different species. Putative transcription factor binding sites were identified using consensus transcription factor binding sequences: STAT5- signal transducers and activators of transcription 5 binding site; YY1- Yin Yang 1 site, GRE1/2- half-palindromic glucocorticoid response elements; MAF- mammary-cell activating factor binding site (Grafische Darstellung der vermeintlichen Transkriptionsfaktorbindungsstellen innerhalb der sechs $\kappa$-Kasein Promotorsequenzen und acht $\beta$-Kasein Promotorsequenzen von verschiedenen Arten. Die Identifikation der vermeintlichen Transkriptionsfaktorbindungsstellen basierte auf den Konsensussequenzen für die Bindung folgender Transkriptionsfaktoren: STAT5- signal transducers and activators of transcription 5 Bindungsstelle; YY1- Yin Yang 1 Stelle, GRE1/2half-palindromic glucocorticoid response elements; MAF- mammary-cell activating factor Bindungsstelle)

Bovine $\beta$ - and $\kappa$-casein gene promoter driven luciferase expression in the BME-UV1 cell line

In the transfection experiment we compared three different casein promoter fragments: $\beta$-casein promoter (-1/-1692), containing BCE1 enhancer element, which has already been studied in different expression systems, and two $\mathrm{k}$-casein promoter fragments of different size (-1/-925 and -1/-2064). The distal portions of the $\kappa$-casein promoter were not subject of extensive functional analysis before. Surprisingly, the luciferase expression was much higher using the $\kappa$-casein promoter, even the short variant, compared to the $\beta$-casein promoter. The transcriptional activity of the short $\kappa$-casein promoter is about 10 fold, and that of the long $\kappa$-casein promoter approximately 15 fold stronger than activity of the $1.7 \mathrm{~kb} \beta$-casein promoter (Fig. 3). Interestingly, the same trend was also observed in the case of equine casein promoter-LUC constructs, which were also expressed, although at significantly lower level, in the bovine BMEUV1 cell system, revealing higher expression level of the equine $\kappa$-casein promoterLUC constructs compared to the equine $\beta$-casein promoter-LUC construct (LENASI et al., manuscript in preparation). 


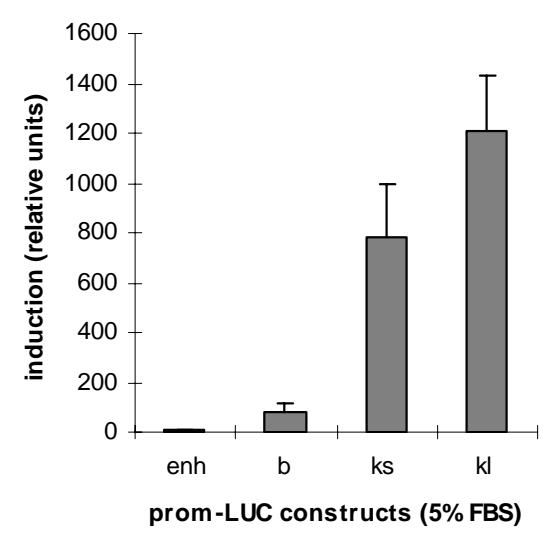

Fig. 3: Functional analysis of the bovine $\kappa$ - and $\beta$-casein promoters. Transient expression of the luciferase reporter gene was measured 48 hrs after transfection and normalized for $\beta$-gal expression. The activity of the short (ks; -925/-1) and long (kl; -2064/+1) $\kappa$-casein promoter-LUC expression vectors was compared with the bovine $\beta$-casein-LUC expression vector (b; -1692/-1). A bar chart shows results of the transient expression experiment in BME-UV1 cells in the presence of 5\% FBS. Luciferase enhancer vector (enh) was used as a negative control (Funktionsanalyse der Rinder $\kappa$ - und $\beta$-Kazeingenpromotoren. Transiente Expression des Luziferase-Reportergens wurde 48 Std. nach der Transfektion gemessen und normalisiert mit der $\beta$-gal Expression. Die Aktivität des kurzen (ks; -925/-1) und langen (kl; -2064/+1) к-Kaseinpromotor-LUCExpressionvektors wurde mit der Expression des Rinder $\beta$-Kasein-LUC-Expressionsvector (b; -1692/-1) verglichen. Das Balkendiagramm zeigt die Ergebnisse des Expressionsexperimentes in den BME-UV1 Zellen bei der Zugabe von 5\% Kälberfötalserums. Luciferase Enhancer Vektor (enh) diente als Negativkontrolle)

\section{Discussion}

Theoretical prediction of the hypothetical TF binding sites can only serve as a first orientation for further functional promoter studies, which can confirm the impact of functional elements within the eukaryotic promoters enhancing or repressing gene expression at transcriptional level. An interspecies comparison of TF binding site organisation within the $\beta$ - and $\kappa$-casein promoters revealed several similarities in the promoter structure. One of the best characterized elements in the $\beta$-casein promoter, BCE-1, which is responsible for hormone dependent regulation of gene expression, is in the human promoter located between nucleotide positions -4729 and -4340 and in the bovine $\beta$-casein promoter between positions -1698 and -1302 (WINKLEHNERJENNEWEIN et al., 1998). The relatively low expression of $\beta$-casein-LUC gene in our experiment could be explained by the fact that BCE- 1 requires integration into chromosomal DNA, growing of cells on extra cellular matrix and hormonal induction by lactogenic hormones for maximal transcription activity (MYERS et al., 1998). Under conditions in our experiment, we were therefore only able to detect basal activity of the bovine $\beta$-casein promoter.

Interspecies comparison of the $\kappa$-casein promoter sequences revealed conserved tandem STAT5 binding sites in the distal part of the promoter. These two sites were already reported as highly conserved in the distal region of the $\kappa$-casein promoter from six species (GERENCZER et al., 2002). The functionality of these two binding sites was in our experiment confirmed by electro mobility shift assay (data not shown). The common characteristics of $\kappa$-casein promoters in cattle and buffalo is the presence of three STAT5 binding sites in the promoter region between nucleotides -1300 and 1000. In our experiment, the long $\kappa$-casein-LUC construct contained all three STAT5 
binding sites, resulting in a markedly higher transcriptional activity compared to the short (925 bp) and 570 bp of the basal $\kappa$-casein promoter (ADACHI et al., 1996).

The surprisingly high transcriptional activity of the $\kappa$-casein promoter compared to the $\beta$-casein promoter in this study is not in line with the physiological proportion of the $\beta$ - and $\kappa$-casein present in bovine milk, where concentration of $\beta$-casein exceeds concentration of $\kappa$-casein for about three fold. Our results can be explained by the fact that in our system only the basal transcriptional activity was measured, without hormonal induction. Difference in response to hormonal induction between calcium sensitive casein genes and $\kappa$-casein gene has already been described (MARTIN et al., 1993). Further experiments including hormonal induction of stable transfected BMEUV 1 cells would be necessary in order to evaluate quantitative aspect of the $\beta$ - and $\kappa$ casein promoter activity in the BME-UV 1 cell system. In addition, intronic sequences and 3' flanking regions, which were not included in our constructs, may contribute considerably to the level of gene expression as well (PETITCLERC et al., 1995). We believe that homologous cell system, used in this experiment, has advantages over the heterologous systems. Our assumption is supported by the low transcriptional activity of the $\kappa$-casein promoter in the murine HC11 cells (ADACHI et al., 1996) and by the significantly lower transcriptional activity of the equine $\beta$ - and $\kappa$-casein promoters in the bovine BME-UV1 cells compared to bovine homologs (LENASI et al., in preparation).

Furthermore, TFs do not affect transcription only by simple binding to corresponding DNA binding site, but also by complex interactions with other proteins involved in the formation of transcription complex. This makes analysis of physiological relevance of particular TF binding sites very complex. The mode of action of the GR for example, depends also on the concentration of the GR (DOPPLER et al., 2001). At low concentrations, GR can act only by binding to its promoter binding site, whereas at high concentrations, GR can act as co-activator of STAT5, even in the absence of a functional DNA binding domain. The transcriptional co-operativity between STAT5, GR and C/EBP $\beta$, dependent on transcriptional active GR, was established using the COS cell reconstitution system. This complex nature of interactions among TFs suggests that putative TF binding sites, determined on the basis of sequence similarity, and confirmed by EMSA, should further be analysed for their functionality using additional functional assays including different cell systems and in vivo models.

From the practical point of view, polymorphisms in the promoter regions of casein genes could explain differential allelic expression of casein genes and allelic differences in cheese making properties. However, in our previous experiments we failed to identify allele specific mutations within the TF binding sites in the proximal bovine $\kappa$-casein promoter (DEBELJAK et al., 2000). The complex nature of TF action makes it possible, that allelic differences in the $\kappa$-casein expression arise from allelic polymorphisms further upstream in the promoter sequence, in the introns or even in the 3'-untranslated region. Identification of functional allelic differences at the DNA level would enable marker assisted selection for cheese making properties in dairy cattle. 


\section{Acknowledgment}

The authors acknowledge technical help of Guštin G., who provided a software tool for TF binding site search in silico. The project is a part of collaborative research in the frame of COST B20 Action "Mammary gland development, function and cancer" and was supported by the research programme \#P4-0220, financed by the Slovenian Research Agency.

\section{References}

ADACHI, T.; AHN, J. Y.; YAMAMOTO, K.; AOKI, N.; NAKAMURA, R.; MATSUDA, T.: Characterisation of the bovine $\kappa$-casein gene promoter. Biosci. Biotech. Biochem. 60 (1996), 1937-1940

AHN, J-Y.; AOKI, N.; ADACHI, T.; MIZUNO, Y.; NAKAMURA, R.; MATSUDA, T.: Isolation and culture of bovine epithelial cells and establishment of gen transfection conditions in the cells. Biosci. Biotech. Biochem. 59 (1995), 59-64

AUBIN, R.A.; WEINFELD, M.; MIRZAYANS, R.; PATERSON, M.C.: Polybrene / DMSO-assisted gene transfer. Generating stable transfectants with nanogram amounts of DNA. Mol. Biotechnol. 1 (1994), 29-48

BONSING, J.; MACKINLAY, A.G.: Recent studies on nucleotide sequences encoding the caseins. J. Dairy Res. 54 (1987), 447-61

CERDAN, M.G.; YOUNG, J.I.; ZINO, E.; FALZONE, T.L.; OTERO, V.; TORRES, H.N.; RUBINSTEIN, M.: Accurate spatial and temporal transgene expression driven by a 3.8-kilobase promoter of the bovine $\beta$ casein gene lactating mouse mammary gland. Molecular Reprod. and Development 49 (1998), 236-245

CHELI, F.; POLITIS, I.; ROSSI, L.; FUSI, E.; BALDI, A.: Effects of retinoids on proliferation and plasminogen activator expression in a bovine mammary epithelial cell line. J. Dairy Res. 70 (2003), 367-72

CHUGHTAI, N.; SCHIMCHOWITSCH, S.; LEBRUN, J.-J.; ALI, S.: Prolactin induces SHP-2 association with Stat5, nuclear translocation, and binding to the $\beta$-casein gene promoter in mammary cells. J. of Biological Chemistry 227 (2002), 31107-31114

DEBELJAK, M.; SUŠNIK, S.; MILOŠEVIČ BERLIČ, T.; MEDRANO, J.F.; DOVČ, P.: Gene technology and milk production. Food Technol. Biotechnol. 38 (2000), 83-89

DOPPLER, W.; WELTE, T.; PHILIPP, S.: CCAAT/Enhancer-binding protein isoforms $\beta$ and $\delta$ are expressed in mammary epithelial cells and bind to multiple sites in the $\beta$-casein gene promoter. J. of Biological Chemistry 270 (1995), 17962-17969

DOPPLER, W.; WINDEGGER, M.; SORATROI, C.; TOMASI, J.; LECHNER, J.; RUSCONI, S.; CATO, A.C.B.; ALMLÖF, T.; LIDEN, J.; OKRET, S.; GUSTAFSSON, J.; RICHARD-FOY, H.; STARR, D.B.; KLOCKER, H.; EDWARDS, D.; GEYMAYER, S.:

Expression level-dependent contribution of glucocrticoid receptor domains for functional interaction with STAT5. Molecular and Cellular Biology, 21 (2001), 3266-6279

FERRETTI, L.; LEONE, P.; SGARAMELLA, V.: Long range restriction analysis of the bovine casein genes. Nucleic Acids Res. 18 (1990), 6829-6833

GALLEGO, M.I.; BINART, N.; ROBINSON, G.W.; OKAGAKI, R.; COSCHIGANO, K.T.; PERRY, J.; KOPCHICK, J.J.; OKA, T.; KELLY, P.A.; HENNIGHAUSEN, L.: Prolactin, growth hormone, and epidermal growth factor activate Stat5 in different compartments of mammary tissue and exert different and overlapping developmental effects. Dev. Biol. 299 (2001), 6375

GERNAND, E.; HARTUNG, H.:

Untersuchungen zu Einflussgrößen auf Zusammensetzung und Käsereitauglichkeit von Rohmilch einzelner Kühe. 2. Mitt.: Untersuchung zur Variation der Milchgerinnung und deren Ursachen an Einzelmilchproben. Arch. Tierz., Dummerstorf 40 (1997) 3, 225-238

GERENCSER, A.; BARTA, E.; BOA, S.; BOSZE, Z.; WHITELAW, B.: Comparative analysis on the structural features of the 5 ' flanking region of kappa-casein genes from six different species. Genet. Sel. Evol. 34 (2002), 117-28

GINGER, M.R.; GRIGOR, M.R.: Comparative aspects of milk caseins. Comp. Biochem. Physiol. Biochem. Mol. Biol. 124 (1999), 13345

HELMAN, D.; SANDOWSKI, Y.; COHEN, Y.; MATSUMOTO, A.; YOSHIMURA, A.; MERCHAV, S.; GERTEL, A.: Cytokine-inducible SH2 protein (CIS3) and JAK2 binding protein (JAB) abolish prolactin receptor.mediated STAT5 signaling. FEBS letters 441 (1998), 287-291 
HENNIGHAUSEN, L.; ROBINSON, G.W.:

Think globally, act locally: the making of a mouse mammary gland. Genes \& Development 12 (1998), 447-455

JANN, O.; PRINZENBERG, E.-M.; BRANDT, H.; WILLIAMS, J. L.; AJMONE-MARSAN, P.; ZARAGOZA, P.; ÖZBEYYAZ, C.; ERHARDT, G.:

Intragenic haplotypes at the bovine CSN1S1 locus. Arch. Tierz., Dummerstorf 45 (2002) 1, 13-21

JUSZCZAK, J.; ERHARDT, G.; KUCZAJ, M.; ZIEMINSKI, R.; PANICKE, L.:

Zusammenhang zwischen $\kappa$-Casein und $\beta$-Lactoglobulin-Varianten mit der Milchleistung und der Nutzungsdauer von Rindern der Rassen Schwarzbuntes Rind und Polnisches Rotvieh. Arch. Tierz., Dummerstorf 44 (2001) 3, 239-249

KANAI, A.; NONOMURA, N.; YOSHIMURA, M.; OKA, T.:

DNA-binding proteins and their cis-acting sites controlling hormonal induction of a mouse beta-casein: CAT fusion protein in mammary epithelial cells. Gene 126 (1993), 195-201

LODES, A.; KRAUSE, I.; BUCHBERGER, J.; AUMAN, J.; KLOSTERMEYER, H.:

The influence of genetic variants of milk proteins on the compositional and technological properties of milk. 1. Casein micelle size and the content of non.glycosylated $\kappa$-casein. Milchwissenschaft 51 (1996), 368-373

MARTIN, P.; GROSCLAUDE, F.:

Improvement of milk protein quality by gene technology. Livestock Prod. Sci. 35 (1993), 95-115

MATITASHVILI, E.; BRAMLEY, A.J., ZAVIZION, B.:

An in vitro approach to ruminant mammary gland biology. Biotechnol. Adv. 15 (1997), 17-41

MYERS, C.A.; SCHMIDHAUSER, C., MELLENTIN-MICHELOTTI, J.; FRAGOSO, G.; ROSKELLEY, C.D;

CASPERSON, G.; MOSSI, R.; PUJUGUET, P.; HAGER, G.; BISSELL, M.:

Characterisation of BCE-1, a transcriptional enhancer regulated by prolactin and extracellular matrix and modulated by the state of histone acetylation. Molecular and Cellular Biology, 18 (1998), 21842195

PETITCLERC, D.; ATTAL, J.; THERON, M.C.; BEARZOTTI, M.; BOLIFRAUD, P.; KANN, G.;

STINNAKRE, M.G.; POINTU, H.; PUISSANT, C.; HOUDEBINE, L.M.:

The effect of various introns and transcription terminators on the efficiency of expression vectors in various cultured cell lines and in the mammary gland of transgenic mice. J. Biotechnol. 49 (1995), 16978

PIRCHNER, F.; GRAML, R.:

Effects of milk protein loci on content of their proteins. Arch. Tierz., Dummerstorf 46 (2003) 4, 331340

RIJNKELS, M.; KOOIMAN, P.M.; DE BOER, H.A.; PIEPER, F.R.:

Organization of the bovine casein gene locus. Mammalian Genome 8 (1997), 148-52

RIJNKELS, M.; KOOIMAN, P.M.; KRIMPENFORT, P.J.; DE BOER, H.A.; PIEPER, F.R.:

Expression analysis of the individual bovine beta-, alpha s2- and kappa-casein genes in transgenic mice. Biochem. J. 311 (1995), 929-37

RIJNKELS, M.; WHEELER, D.A.; DE BOER, H.A.; PIEPER, F.R.: Structure and expression of the mouse casein gene locus. Mammalian Genome 8 (1997), 9-15

ROBINSON, G.W.; JOHNSON, P.F.; HENNIGHAUSEN, L.; STERNECK, E.:

The C/EBPbeta transcription factor regulates epithelial cell proliferation and differentiation in the mammary gland. Genes Dev. 12 (1998), 1907-1916

ROSEN, J.M.; WYSZOMIERSKI, S.L.; HADSELL, D.:

Regulation of milk protein gene expression. Annu. Rev. Nutr. 19 (1999), 407-436

SCHMIDHAUSER, C.; CASPERSON, G.F.; MYERS, C.A.; SANZO, K.T.; BOLTEN, S.; BISSELL, M.J.:

A novel transcriptional enhancer is involved in the prolactin- and extracellular matrix-dependent regulation of beta-casein gene expression. Mol. Biol. Cell. 3 (1992), 699-709

TOMIC, S.; CHUGHTAI, N.; ALI, S.:

SOCS-1, -2, -3: selective targets and functions downstream of the prolactin receptor. Molecular and Cellular Endocrinology 158 (1999), 45-54

WATSON, C.J.; GORDON, K.E.; ROBERTSON, M.; CLARK, A.J.: Interaction of DNA-binding proteins with a milk protein gene promoter in vitro: identification of a mammary gland-specific factor. Nucl. Acids Res. 19 (1991), 6603-6610

WELTE, T.; PHILIPP, S.; CAIRNS, C.; GUSTAFSSON, J.A.; DOPPLER, W.: Prolactin-dependent activation of a tyrosine phosphorylated DNA binding factor in mouse mammary epithelial cells. J. Steroid Biochem. Mol. Biol. 47 (1993), 75-81

WHEELER, T.T.; BROADHURST, M.K.; SADOWSKI, H.B.; FARR, V.C.; PROSSER, C.G.:

Stat5 phosphorylation status and DNA-binding activity in the bovine and murine mammary glands. Molecular and Cellular Endocrinology 176 (2001), 39-48 
WINKLEHNER-JENNEWEIN, P.; GEYMAYER, S.; LECHNER, J.; WELTE, T.; HANSSON, L.; GELEY, S.; DOPPLER, W.:

A distal enhancer region in the human $\beta$-casein gene mediates the response to prolactin and glucocorticoid hormones. Gene 217 (1998), 127-139

WYSZOMIERSKI, S.L.; ROSEN, J.M.:

Cooperative effects of STAT5 (signal transducer and activator of transcription 5) and C/EBP $\beta$ (CCAAT/enhancer binding protein- $\beta$ ) on $\beta$-casein gene transcription are mediated by the glucocorticoid receptor. Molecular Endocrinology 15 (2001), 228-240

YAMASHITA, H.; NEVALAINEN, M.T.; XU, J.; LEBARON, M.J.; WAGNER K.U.; ERWIN, R.A.;

HARMON, J.M.; HENNIGHAUSEN, L.; KIRKEN, R.A.; RUI, H.:

Role of serine phosphorylation of Stat5a in prolactin-stimulated $\beta$-casein gene expression. Molecular and Cellular Endocrinology 183 (2001), 151-163

ZAVIZION, B.; VAN DUFFELEN, M.; SCHAEFFER, W.; POLITIS I.:

Establishment and characterization of a bovine mammary epithelial cell line with unique properties. In Vitro Cell Dev. Biol. Anim. 32 (1996), 138-48

Received: 2004-11-03

Accepted: 2005-06-16

Author's addresses

MARUSA DEBELJAK, PhD., POLONA FRAJMAN, dvm, MOJCA NARAT, PhD.,

TINA LENASI, PhD., Prof. PETER DOVC, PhD.*

Department of Animal Science, Biotechnical Faculty,

University of Ljubljana,

Groblje 3,

SI-1230 Domzale, Slovenia

Prof. ANTONELLA BALDI, PhD., Institute of Animal Nutrition,

Veterinary Faculty, University of Milan, Via Trentacoste 2,

I-20134 Milan, Italy

*Corresponding author

E-Mail: peter.dovc@bfro.uni-lj.si 